\author{
생리활성 물질(쑥, 두충 및 어성초)의 첨가가 이유자돈의 성장, \\ 영양소 이용율, 혈액특성, 장내 미생물 및 설사빈도에 미치는 영향 \\ 김재황* . 안경호**. 고영두** \\ 한국응용미생물산업연구소*, 경상대학교 응용생명과학부**
}

\title{
Effects of Supplemental Bio-Active Substances on the Growth Performance, Nutrient Utilization, Blood Characteristics, Microflora Population and Diarrhea Frequency of Weanling Pigs
}

\author{
J. H. Kim*, G. H. Ahn** and Y. D. Ko* \\ Korea Applied Microorganism Industrial Research*, \\ College of Agriculture and Life Science, Gyeongsang National University**
}

\begin{abstract}
This study was conducted to investigate the effects of a supplemented mixture of herbs (artemisia, eucommia ulmoids and houttuynia cordata) on the growth performance, nutrient utilization, blood characteristics, microflora population and diarrhea frequency in weanling pigs. Eighty-four pigs were randomly allotted into one of the four dietary treatments, each of which had 3 replicates. Experimental diets were prepared by adding (0.0, 0.5, 1.0 and $2.0 \%$ ) a mixture of artemisia, eucommia ulmoids and houttuynia cordata to a commercial feed, and were given to pigs for 42 days. Daily feed intake was significantly increased in the groups supplemented with the mixture at $1.0 \%$ group and $2.0 \%$ group. Digestibility was significantly increased in $1.0 \%$ for protein and ether extract, and in $1.0 \%$ group and $2.0 \%$ group for NFE. Total bacillus and lactobacillus sp. were significantly $(\mathrm{p}<0.05)$ improved in $1.0 \%$ group and $2.0 \%$ group, respectively. Glucose concentrations of serum increased significantly $(\mathrm{p}<0.05)$ in $0.5 \%$ group and $1.0 \%$ group, and HDL increased significantly $(\mathrm{p}<0.05)$ in $1.0 \%$ group and $2.0 \%$ group. Diarrhea decreased by treatments except control $(\mathrm{p}<0.05)$. It is concluded that pigs fed the diet supplemented with $1.0 \%$ mixture of herbs can improve daily body weight gain, feed efficiency, nutrient utilizations and diarrhea frequency in pigs.
\end{abstract}

(Key words: Mixture of herbs, Growth performance, Blood characteristics, Microflora population, Diarrhea frequency)

$$
\text { I. 서 론 }
$$

쑥은 우리나라 자생종만도 약 30 여 종이 산 야지, 과수원 밑과 구릉지 등에서 널리 서식하

고 있다. 영양적 특성은 alkaloid, vitamin $\mathrm{A}, \mathrm{B}$,

$\mathrm{C}$, 철분, 칼슘 및 인 등이 다량으로 함유되어
있으며(이, 1965), 한방에서는 복통, 소화작용, 구충, 악취제거, 위장병, 변비, 기관지염 및 신 경통 등에 널리 쓰이며(허, 1978), 혈청 콜레스 테롤의 감소와 지혈 효과(정와 신, 1990), 쑥 즙 액의 약리 효과(류와 황, 1994) 및 암세포 증식 억제 효과(황 등, 1998) 등에 대하여 보고되고

Corresponding author : G. H. Ahn, Animal Science Major, Division of Animal Science and Technology, College of Agriculture and Life Science, Gyeongsang National University Jinju, 660-701, Korea. Tel : 055-751-5512, E-mail: jh58kim@naver.com 
있다. 한편 두충은 조단백질 함량이 약 $30 \%$ 로 서 매우 높고 조지방 함량은 약 $7 \%$, 조섬유 함 량은 약 $20 \%$ 로서 사료적 가치도 높다. 이러한 두충에는 alkaloid, pectin, 지질, 유기산, 당류 및 vitamin C 등이 함유되어 있으며, phenol성 화 합물이 함유되어 있어 혈압 강하작용(Metori 등, 1997), 이뇨작용과 항당뇨 활성(Hwang 등, 1996), cholesterol 저하 및 비만방지(Nakasa 등, 1995) 등의 효과가 있다. 두충 잎 추출물을 흰쥐에 급여 시 간 기능의 회복효과와 혈청지질 개선 효과(전과 박, 2002), 혈중 DHL-콜레스테롤 증가, 총 콜레스테롤 감소 및 배변효과(김과 왕, 1997) 등이 보고되고 있다. 또한 어성초는 일본과 중국이 원산지이며 한방과 민방에서 염 증, 해독, 치칠 및 약창 등의 치료에 널리 이용 되고 있으며(문, 1994), 지질과산화 억제작용, 콜 레스테롤 감소, 항돌연변이, 항산화 활성, 항균 활성, 중금속 독성억제 및 간 기능 보호에 탁 월한 효과가 있다(김 등, 1997; 이 등, 2001; 김, 2002), 특히 최근에는 민방에서 엑기스, 환, 건 조분말 등으로 제품화되어 건강보조 식품으로 이용하고 있다.

이상과 같이 현재까지 약용식물(쑥, 두충 및 어성초)의 약리적 효과에 대한 관심으로 대부 분 인체에 적용하기 위한 생약분야의 연구에 국한 되어 왔으며, 반추동물에 대한 연구는 다 수 발표(Kim 등, 2002a; Kim 등, 2002b; 김과 고, 2005; 김, 2005; 김과 고, $2005 \mathrm{a}$; 김과 고, 2005b; Ko 등, 2006) 되었으나, 돼지에 대한 약용식물의 활용 방안 뿐 만 아니라 생리활성
물질에 의한 사료 이용율 개선, 혈액성상 및 질병예방 효과에 대한 연구는 전무한 실정이 다.

따라서 본 연구에서는 한방과 민방에서 널 리 이용되고 약리적 효과가 높은 쑥에 두충 및 어성초를 혼합한 분말을 이유자돈 사료에 첨가 하여 이유자돈의 성장, 영양소 이용율, 혈액성 상, 장내 미생물 및 설사빈도에 미치는 효과를 구명하고자 실시하였다.

\section{ㅍ. 재료 및 방법}

\section{1. 공시동물 및 시험기간}

사양시험은 2005년 3월부터 5월까지 경남 산 청군 소재 산청양돈영농조합법인에서 사육중인 3원교잡종 [(Landrace $\times$ Yorkshire $) \times$ Duroc] 이유 자돈(평균체중 $7.95 \pm 1.43 \mathrm{~kg}, 42$ 일간 시험)을 공 시하여 수행하였다.

\section{2. 시험설계}

쑥, 두충 및 어성초를 70:15:15로 혼합한 분 말을 이유자돈 사료에 일정비율로 첨가하여 생 산성에 미치는 영향을 구명하기 위하여 이유자 돈용 배합사료만을 급여한 무첨가구와 배합사 료에 쏙, 두충 및 어성초의 혼합분말을 $0.5,1.0$ 및 $2.0 \%$ 첨가한 구로 나누어 한 돈방에 7 두를 수용하여 3 반복으로 총 84 두를 완전임의 배치 하였다.

Table 1. The chemical composition of Artemisia, Eucommial Leaf and Houttuynia cordata used in experiment

\begin{tabular}{|c|c|c|c|c|}
\hline Items & Artemisia(A) & Eucommial Leaf(E) & Houttuynia cordata(H) & $\mathrm{A}+\mathrm{E}+\mathrm{H}$ \\
\hline & \multicolumn{4}{|c|}{ 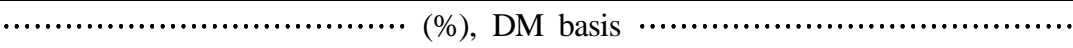 } \\
\hline Dry matter & $88.14 \pm 1.03^{\mathrm{a}}$ & $89.81 \pm 0.98^{\mathrm{a}}$ & $78.92 \pm 0.57^{\mathrm{b}}$ & $86.27 \pm 1.00^{\mathrm{a}}$ \\
\hline Crude protein & $17.55 \pm 0.69^{b}$ & $19.53 \pm 0.61^{\mathrm{a}}$ & $2.37 \pm 0.82^{\mathrm{c}}$ & $16.45 \pm 0.81^{\mathrm{b}}$ \\
\hline Ether extract & $3.67 \pm 0.69^{\mathrm{bc}}$ & $6.83 \pm 1.01^{\mathrm{a}}$ & $1.86 \pm 0.73^{\mathrm{C}}$ & $4.28 \pm 0.87^{\mathrm{ab}}$ \\
\hline Crude fiber & $21.78 \pm 0.69^{b}$ & $19.16 \pm 0.61^{\mathrm{a}}$ & $3.65 \pm 0.82^{\mathrm{c}}$ & $18.56 \pm 0.81^{b}$ \\
\hline NFE & $45.80 \pm 0.56^{\mathrm{c}}$ & $46.26 \pm 1.03^{\mathrm{c}}$ & $89.14 \pm 0.83^{\mathrm{a}}$ & $54.06 \pm 0.72^{\mathrm{b}}$ \\
\hline
\end{tabular}

$\mathrm{n}=3$.
$\mathrm{a}, \mathrm{b}, \mathrm{c}$
Means $\pm \mathrm{SD}$ with different superscripts in the same row differ significantly $(\mathrm{p}<0.05)$. 


\section{3. 시험사료}

시험원료인 쑥, 두충 및 어성초는 경남 진주 인근에서 채취하여 3 일간 음건시킨 후 사용하였 으며, 사료에 첨가방법 $(0.0,0.5,1.0$ 및 $2.0 \%)$ 은 $200 \mathrm{~kg}$ 용 사료 배합기를 이용하여 처리구별로 쑥, 두충 및 어성초를 배합한 후 평판 저울로 $10 \mathrm{~kg}$ 씩 계량하여 급여하였다. 본 시험에 이용된 쑥, 두충 및 어성초의 화학적 조성은 Table 1과 같으며, 배합사료는 시판 배합사료를 이용하였으 며, 배합비율과 화학적 조성은 Table 2와 같다.

\section{4. 사양 관리}

돈방의 크기는 $2.0 \mathrm{~m} \times 0.8 \mathrm{~m}\left(0.32 \mathrm{~m}^{2}\right.$ /두 $)$ 이며, 돈사 구조는 무창 슬러리 돈사이고 돈방 바닥 은 전면 플라스틱 베드를 사용하였다. 사료급 여는 이유자돈용 원형사료 건식급이기를 사용하 여 자유채식토록 하였다. 급수방법은 돈방 벽에 부착되어 있는 니플을 이용하였다.

\section{5. 조사항목 및 분석방법}

\section{1) 사료의 일반성분}

일반성분 분석시료는 $65^{\circ} \mathrm{C}$ 의 건조기에서 3 일 간 건조시킨 후 분쇄기(hammer mill)를 이용하 여 $1 \mathrm{~mm}$ 입자로 분쇄한 후 사용하였다. 시험사 료와 분의 일반성분 중 건물은 상압가열건조 법, 조단백질 함량은 조단백질 소화장치와 자동 분석기(Kjeldahl Unit, Germany), 조지방은 Soxhlet 추출법을 이용하여 측정하였다(AOAC, 1995).

\section{2) 증체량과 사료섭취량}

증체량은 시험 종료시 체중에서 개시시 체중 을 뺀 후 사육기간으로 나누어 계산하였으며, 사료섭취량은 시험기간 동안 오전 8시 30분, 오 후 1 시 30 분 및 오후 5시에 각각 $10 \mathrm{~kg}$ 씩 나누어 급여하였으며 매 급여시 잔량을 측정하 여 급여량에서 잔량을 제외한 후 사육기간으로 나누어 계산하였다.

3) 영양소 이용율
Table 2. Formula and chemical compositions of basic diets

\begin{tabular}{|c|c|}
\hline Items & $\begin{array}{c}\text { Weanling } \\
\text { pigs }(10 \sim 25 \mathrm{~kg})\end{array}$ \\
\hline \multicolumn{2}{|l|}{ Ingredients, (\%) } \\
\hline Corn & 67.99 \\
\hline Soybean meal & 21.00 \\
\hline Wheat bran & 2.80 \\
\hline Rice bran oil & 4.00 \\
\hline DL-Methionine, $50 \%$ & 0.14 \\
\hline L-Lysine. $\mathrm{HCl}, 98.5 \%$ & 0.44 \\
\hline L-Threonine, $100 \%$ & 0.03 \\
\hline Tricalcium phosphate & 1.50 \\
\hline Salt & 0.02 \\
\hline Limestone & 1.00 \\
\hline Vitamin-Mineral mix ${ }^{1)}$ & 0.70 \\
\hline Antibiotics $^{2)}$ & 0.10 \\
\hline Olaquindox & 0.10 \\
\hline \multicolumn{2}{|c|}{ Chemical composition, \%, (DM basis) } \\
\hline Crude protein & 16.16 \\
\hline Ether extract & 6.14 \\
\hline Crude fiber & 2.16 \\
\hline Crude ash & 5.38 \\
\hline $\mathrm{Ca}$ & 0.78 \\
\hline $\mathrm{P}$ & 0.67 \\
\hline Lysine & 0.96 \\
\hline Cystine & 0.27 \\
\hline Methionine & 0.28 \\
\hline $\mathrm{DE}(\mathrm{Kcal} / \mathrm{kg})$ & 3,253 \\
\hline
\end{tabular}

1) Vitamin-Mineral mix: vit A, 2,500,000IU ; vit $\mathrm{D}_{3}$, $500,000 \mathrm{IU}$; vit E, $750 \mathrm{mg}$; thiamin, $1,000 \mathrm{mg}$; riboflavin, $1,5000 \mathrm{mg}$; vit $\mathrm{B}_{6}, 250 \mathrm{mg}$, pantotheniate, 3,500 mg ; niacin, $750 \mathrm{mg}$; choline, 5,000 mg; iron, 50,000 mg; copper, 5,000 mg; zinc, 25,000 mg; manganes, 15,000 mg; cobalt, $250 \mathrm{mg}$; iodine, $100 \mathrm{mg}$.

2) Antibiotics contained $10.25 \mathrm{mg}$ chlorooxytetracycline per $\mathrm{kg}$.

처리별 영양소 이용율은 사양시험 종료 7일 전에 $\mathrm{Cr}_{2} \mathrm{O}_{3}$ 분석법으로 시험사료에 $\mathrm{Cr}_{2} \mathrm{O}_{3}$ 를 $0.1 \%$ 첨가.급여하여 4 일간의 예비시험과 5 일 간의 본시험으로 나누어 실시하였다. 분의 채 취는 본시험 기간 중에 오전 10시와 오후 3시 로 나누어 1 일 총 2회 수집하였으며, 1 회 약 $50 \mathrm{~g}$ 을 여러 곳에서 수집하여 비닐 백에 넣고 밀봉한 후 분석에 이용하였다. 
4) 분변 내 미생물총

분변 내 미생물총은 사양시험 종료 직후 배 설된 즉시의 신선한 분을 $10 \mathrm{~g}$ 씩 채취하여 petri dish에 옮겨 담은 후, $121^{\circ} \mathrm{C}$ 에서 15 분간 멸균시킨 생리식염수를 이용하여 $10^{-11}$ 까지 십진 희석한 다 음, 균수 측정을 위하여 평판배지에 분주. 접종 하여 도말하였다. Total Bacillus와 Lactobacillus sp. 는 MRS agar 배지를 이용하여 $35^{\circ} \mathrm{C}$ 에서 Total Bacillus는 24시간, Lactobacillus sp.는 48시간 배 양하였다. E. Coli는 MacConkey agar 배지를 이 용하여 $25^{\circ} \mathrm{C}$ 에서 24 시간 호기상태로 배양하였 으며, 각각의 평판배지에 생성된 colony 수(30 300개)는 colony counter를 이용하여 계수하였 다.

\section{5) 혈액성분}

채혈을 위하여 3시간 동안 절식을 시킨 후 각 처리구에서 무작위로 선발된 5두의 목부위 경정맥으로부터 혈액을 혈액 응고방지제가 첨 가되지 않은 $10 \mathrm{ml}$ 주사기를 이용하여 혈액을 약 $8 \mathrm{ml}$ 채취하여 실온에서 약 30 분간 방치 후 분리된 상등액(혈청 부분)을 일반 혈액채취용 시험관에 옮겨 넣은 다음 혈액계수기(Vet-ABC, USA)와 혈액생화학 분석기(Express Plus, USA) 를 이용하여 분석하였다.

\section{6) 설사빈도}

오전 8시부터 오후 6시까지 2시간 간격으로 1 일 총 6 회 분과 항문의 상태를 관찰하여 설사 빈도를 조사하였다.

\section{6. 통계분석}

본 시험에서 얻어진 결과들은 SAS Package program (1999)를 이용하여 분석하였으며, 처리 간 유의차 검정은 Duncan's multiple range test (1955)을 이용하여 5\% 수준에서 실시하였다.

\section{III. 결과 및 고찰}

\section{1. 증체량, 사료섭취량 및 사료효율}

쑥, 두충 및 어성초를 혼합하여 이유자돈 사 료에 첨가수준 $(0.0,0.5,1.0$ 및 2.0\%) 별로 급여 하여 증체량, 사료섭취량 및 사료효율을 조사 한 결과는 Table 3 과 같다.

시험 개시시 체중은 모든 처리구에서 7.63 $8.37 \mathrm{~kg}$ 으로 차이는 없었으나 시험 종료시 체중 은 $1.0 \%$ 첨가구에서 $27.00 \mathrm{~kg}$ 으로서 대조구와 $0.5 \%$ 첨가구에 비하여 증가하였다 $(\mathrm{p}<0.05)$. 그 러나 일당 증체량은 $0.0,0.5,1.0$ 및 $2.0 \%$ 첨가 구에서 각각 $0.41,0.45,0.48$ 및 $0.47 \mathrm{~kg}$ 으로서 무첨가구에 비해 첨가구가 높은 경향이었으나 유의차는 없었다( $>00.05)$. 일당 사료섭취량은 무 첨가구가 $0.54 \mathrm{~kg}, 0.5 \%$ 첨가구가 $0.57 \mathrm{~kg}$ 로 차 이는 없었고( $>>0.05), 1.0 \%$ 첨가구와 $2.0 \%$ 첨가 구는 각각 $0.65 \mathrm{~kg}, 0.63 \mathrm{~kg}$ 으로 무첨가구에 비 하여 유의차 $(\mathrm{p}<0.05)$ 가 있었다. 사료효율은 무 첨가구, $0.5 \%, 1.0 \%$ 및 $2.0 \%$ 가 각각 $0.76,0.79$. 074 및 0.75 로서 유의차가 없었다 $(\mathrm{p}>0.05)$.

권 등(2005)은 약용식물인 인진쑥, 오가피 및

Table 3. Effects of dietary bio-active substances on the growth performance of weanling pigs

\begin{tabular}{lcccc}
\hline \multirow{2}{*}{ Items } & \multicolumn{3}{c}{ Supplementation levels(\%) } & of bio-active substances $^{1)}$ \\
\cline { 2 - 5 } & 0.0 & 0.5 & 1.0 & 2.0 \\
\hline \hline Initial body weight (kg) & $8.02 \pm 0.33$ & $7.65 \pm 0.25$ & $8.37 \pm 0.33$ & $7.63 \pm 0.41$ \\
Final body weight (kg) & $24.17 \pm 0.56^{\mathrm{b}}$ & $25.17 \pm 0.38^{\mathrm{b}}$ & $27.00 \pm 0.52^{\mathrm{a}}$ & $25.83 \pm 0.46^{\mathrm{ab}}$ \\
Daily gain (kg) & $0.41 \pm 0.04$ & $0.45 \pm 0.04$ & $0.48 \pm 0.03$ & $0.47 \pm 0.06$ \\
Daily feed intake (kg) & $0.54 \pm 0.03^{\mathrm{b}}$ & $0.57 \pm 0.02^{\mathrm{ab}}$ & $0.65 \pm 0.04^{\mathrm{a}}$ & $0.63 \pm 0.04^{\mathrm{a}}$ \\
Feed efficiency (gain/feed) & $0.76 \pm 0.02$ & $0.79 \pm 0.03$ & $0.74 \pm 0.03$ & $0.75 \pm 0.02$ \\
\hline
\end{tabular}

$\mathrm{n}=3$.

1) Mixtures of Artemisia 70\%, Eucommia leaf $15 \%$ and Houttuynia cordata $15 \%$.

a,b Means \pm SD with different superscripts in the same row differ significantly $(\mathrm{p}<0.05)$. 
마늘을 이유자돈에 첨가할 경우 일당 증체량은 약용식물을 첨가함에 따라 차이는 보이지 않았 지만 사료효율은 개선된다고 하였으며, 홍 등 (2002)은 citrus와 chestnut 추출물을 이유자돈에 첨가할 경우 항생제 무첨가구 보다 성장률이 개선되었다고 하였다. 반면 Gerbert 등(1999)은 7 가지 허브와 이들의 혼합물을 자돈에 급여할 경우 성장률에는 차이가 없지만 사료섭취량은 대조구에서 가장 높다고 하였다.

본 연구의 결과 쑥, 두충 및 어성초 분말을 추가 급여함으로서 성장률과 사료효율에는 차 이가 없으면서 사료섭취량에만 차이가 나타나 다른 연구자들과 다소 상이한 결과를 보였다. 이와 같은 결과는 공시사료로 이용한 약용식물 의 재료, 돈사환경, 품종, 모돈의 영양상태 및 관리자의 사양관리 방법 등 여러 가지 요인의 차이에 의한 결과로 생각한다. 특히 쏙, 두충 및 어성초를 혼합하여 급여할 경우 사료섭취량 이 높은 것은 쑥, 두충 및 어성초의 기능성 물 질에 의한 장내 유익균 증가 등이 소화와 흡수 를 위한 장내 환경을 개선에 따른 소화율의 증 가(Table 4)에서 기인한 결과로 기호성이 개선 되었기 때문으로 생각된다.

\section{2. 영양소 이용율}

쑥, 두충 및 어성초를 혼합하여 이유자돈 사 료에 첨가수준 $(0.0,0.5,1.0,2.0 \%)$ 별로 급여하 여 영양소 이용율을 조사한 결과는 Table 4 와 같다.
건물 소화율은 무첨가구가 $82.48 \%$ 였으며, 쏙, 두충, 어성초를 첨가한 모든 처리구에서도 83.62 $\sim 84.73 \%$ 로서 무첨가구와 유의한 차이는 없었다.

건물 소화율은 쑥, 두충 및 어성초를 혼합 첨가함으로서 다소 증가하는 경향이지만 무첨 가구를 포함한 모든 처리구에서 82.48 84.73\% 로서 유의차는 없었다 $(\mathrm{p}>0.05)$. 조단백질 소화 율은 $1.0 \%$ 첨가구가 $82.48 \%$ 로서 무첨가구의 $80.04 \%$ 에 비하여 높았으며 $(\mathrm{p}<0.05)$, 쑥, 두충 및 어성초를 혼합 첨가한 모든 처리구 간에는 차 이가 없었다(p>0.05). 조지방 소화율 역시 조단 백질 소화율과 같은 경향이었다. 즉 무첨가구 는 $71.09 \%$ 였으며 $1.0 \%$ 첨가구에서는 $73.34 \%$ 로 서 가장 높았으며 $(\mathrm{p}<0.05)$, 쑥, 두충 및 어성초 를 혼합 첨가한 모든 처리구 간에는 차이가 없 었다(p>0.05). NFE 소화율은 무첨가구는 $85.54 \%$ 였으며 $1.0 \%$ 첨가구와 $2.0 \%$ 첨가구는 각각 $88.60 \%$ 와 $87.87 \%$ 로서 유의차 $(\mathrm{p}<0.05)$ 가 있었으 며, $0.5 \%$ 첨가구와는 차이가 없었다(p>0.05).

권 등(2005)은 약용식물인 인진쑥, 오가피 및 마늘을 이유자돈에 첨가할 경우 건물소화율은 약용식물을 첨가함으로서 증가하였으나 질소, 칼슘 및 인의 소화율은 약용식물 첨가구에서 높 았으나 유의한 경향은 보이지 않았다고 하였다. 또한 Manzarnilla 등(2004)은 oregano, cinnamon 및 mexican pepper를 이유자돈에 급여할 경우 영양소 소화율에는 차이가 없었다고 보고하였 다.

그러나 본 연구에서는 조단백질과 조지방 및 $\mathrm{NFE}$ 소화율에 있어서 쑥, 두충 및 어성초를 혼

Table 4. Effect of dietary bio-active substances on the nutrient digestibilities of weanling pigs

\begin{tabular}{|c|c|c|c|c|}
\hline \multirow{2}{*}{ Items } & \multicolumn{4}{|c|}{ Supplementation levels(\%) of the bio-active substances ${ }^{1)}$} \\
\hline & 0.0 & 0.5 & 1.0 & 2.0 \\
\hline & \multicolumn{4}{|c|}{ 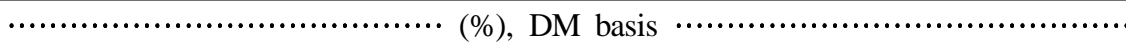 } \\
\hline Dry matter & $82.48 \pm 1.03$ & $83.62 \pm 0.98$ & $84.73 \pm 0.57$ & $84.30 \pm 1.00$ \\
\hline Crude protein & $80.04 \pm 0.69^{b}$ & $81.54 \pm 0.61^{\mathrm{ab}}$ & $82.48 \pm 0.82^{\mathrm{a}}$ & $81.95 \pm 0.81^{\mathrm{ab}}$ \\
\hline Ether extract & $71.09 \pm 0.69^{b}$ & $72.44 \pm 1.01^{\mathrm{ab}}$ & $73.34 \pm 0.73^{\mathrm{a}}$ & $73.12 \pm 0.87^{\mathrm{ab}}$ \\
\hline NFE & $85.54 \pm 0.56^{\mathrm{b}}$ & $86.69 \pm 1.03^{\mathrm{ab}}$ & $88.60 \pm 0.83^{\mathrm{a}}$ & $87.87 \pm 0.72^{a}$ \\
\hline
\end{tabular}

$\mathrm{n}=3$.

1) Mixtures of Artemisia 70\%, Eucommia leaf 15\% and Houttuynia cordata 15\%.

${ }^{\mathrm{a}, \mathrm{b}}$ Means \pm SD with different superscripts in the same row differ significantly $(\mathrm{p}<0.05)$. 
합 첨가함으로서 대조구에 비하여 증가하는 경 향이었으며, 특히 $1.0 \%$ 를 첨가할 경우에는 이 들 소화율이 크게 향상되는 경향으로서 다른 연구자들과 상반된 결과를 나타내고 있다. 이 와 같은 결과 역시 공시사료로 이용한 약용식 물의 재료, 돈사환경, 품종, 모돈의 영양상태 및 관리자의 사양관리 방법 등 여러 가지 요인 의 차이에 의한 결과로 생각한다. 그러나 쑥, 두 충 및 어성초의 항균 활성효과(Deans와 Ritchie, 1987; 송 등, 2003)와 장내 유익균에 대한 성장 촉진효과 및 유해균 억제 능력의 발현(임, 1992; 송, 2000)에 의해 이유자돈의 영양소 소화율이 증진된 것으로 생각된다.

\section{3. 분변 내 미생물총}

쑥, 두충 및 어성초를 혼합하여 이유자돈 사 료에 첨가수준 $(0.0,0.5,1.0,2.0 \%)$ 별로 급여하 여 분변 내 미생물총을 조사한 결과는 Table 5 와 같다.

분변 내 Total bacillus는 $1.0 \%$ 첨가구와 $2.0 \%$ 첨가구에서 각각 $1.77 \times 10^{10}$ 과 $3.70 \times 10^{9} \mathrm{cfu} / \mathrm{g}$ 으 로서 무첨가구 $\left(3.40 \times 10^{8} \mathrm{cfu} / \mathrm{g}\right)$ 와 $0.5 \%$ 첨가구 의 $3.81 \times 10^{8} \mathrm{cfu} / \mathrm{g}$ 에 비하여 높은 경향이었다. 유산균인 Lactobacillus sp.의 경우에도 무첨가구 $\left(2.23 \times 10^{8} \mathrm{cfu} / \mathrm{g}\right)$ 와 $0.5 \%$ 첨가구의 $2.55 \times 10^{8} \mathrm{cfu} / \mathrm{g}$ 에 비해 $1.0 \%$ 첨가구가 $8.17 \times 10^{9} \mathrm{cfu} / \mathrm{g}, 2.0 \%$ 첨가구가 $1.56 \times 10^{9} \mathrm{cfu} / \mathrm{g}$ 로 높게 나타나 Total bacillus와 비슷한 경향을 보였다. 그러나 $E$. coli (coliforms)는 무첨가구를 포함한 모든 처리
구에서 $1.53 \sim 5.03 \times 10^{4}$ 으로 처리구간에 차이는 없었다.

Lee 등(1995)은 마우스에게 쑥 추출물을 5 $10 \%$ 급여할 경우 장내 유익균인 bifidobactera는 증가하고 유해균인 E. coli는 감소한다고 하였 다. 그러나 이와 같은 추출물질에 대한 항미생 물적 작용기전이 완전히 밝혀진 것은 아니지 만 Nagy와 Tengerdy(1968)는 쑥 추출물이 장내 pathogens의 성장을 방해하기 때문이라고 보고 하고 있다. Smith(1965)는 신생자돈은 3시간 후 에 E. coli와 Streptococci 및 Lactobacilli가 검출 되었으며 24시간에 최고치에 달하며 그 후 위 와 소장에서 E. coli와 Streptococci는 감소하므 로 초기에 동물의 장내에 정착되는 세균의 종 류가 앞으로의 동물 건강에 중대한 영향을 끼 친다고 하였다. $\mathrm{Fox}(1988)$ 는 동물이 지속적으 로 stress를 받으면 유산균이 감소하고 E. coli 가 증가하여 장염을 일으키고 설사를 유발한 다고 하였으며, 백(1989)은 건강한 돼지는 장내 에 Streptococcus sp.와 Lactobacillius sp.가 많으 나 설사한 돼지는 장내에 E. coli는 증가하고, Streptococcus sp.는 감소하며 Lactobacillius sp.는 사멸된다고 하였다.

따라서 본 연구에서도 $1.0 \%$ 급여구에서 장내 환경이 개선되어 유익균인 Lactobacillus sp.의 함량이 높아져 항균활동이 증진되었기 때문으 로 생각되며, 쑥, 두충 및 어성초를 혼합한 생 리활성 물질은 자돈의 stress와 장염 및 설사 방지에도 효과적일 뿐 만 아니라 항생제 대체 효과도 매우 클 것으로 생각된다.

Table 5. Effect of dietary bio-active substances on the microflora population in the feces of Weanling pigs(wet matter)

\begin{tabular}{|c|c|c|c|c|}
\hline \multirow{2}{*}{ Items } & \multicolumn{4}{|c|}{ Supplementation levels(\%) of bio-active substances ${ }^{1)}$} \\
\hline & 0.0 & 0.5 & 1.0 & 2.0 \\
\hline & 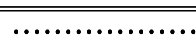 & 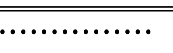 & g) $\ldots \ldots \ldots \ldots \ldots$ & 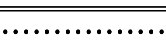 \\
\hline Total bacillus & $3.40 \times 10^{8}$ & $3.81 \times 10^{8}$ & $1.77 \times 10^{10}$ & $3.70 \times 10^{9}$ \\
\hline Lactobacillus sp. & $2.23 \times 10^{8}$ & $2.55 \times 10^{8}$ & $8.17 \times 10^{9}$ & $1.56 \times 10^{9}$ \\
\hline E. Coli & $5.03 \times 10^{4}$ & $4.08 \times 10^{4}$ & $1.53 \times 10^{4}$ & $1.87 \times 10^{4}$ \\
\hline
\end{tabular}




\section{4. 혈액 성상}

쑥, 두충 및 어성초를 혼합하여 이유자돈 사 료에 첨가수준 $(0.0,0.5,1.0,2.0 \%)$ 별로 급여하 여 혈액성상을 조사한 결과는 Table 6과 같다.

혈 중 glucose 함량은 무첨가구는 $114.04 \mathrm{mg} /$ $\mathrm{dl}$ 였으며 $0.5 \%$ 첨가구와 $1.0 \%$ 첨가구는 각각 $144.85 \mathrm{mg} / \mathrm{dl}$ 와 $159.07 \mathrm{mg} / \mathrm{dl}$ 로서 유의차 $(\mathrm{p}<0.05)$ 가 있었다. 그러나 $2.0 \%$ 첨가구는 $138.64 \mathrm{mg} / \mathrm{dl}$ 로서 다른 처리구와는 차이가 없었다 $(\mathrm{p}>0.05)$. Total protein 함량은 무첨가구가 $5.70 \mathrm{~g} / \mathrm{dl}$ 였으며 쑥, 두충 및 어성초를 혼합급여한 모든 처리구 에서는 $6.27 \sim 6.47 \mathrm{~g} / \mathrm{dl}$ 로서 무첨가구에 비해 유 의차 $(\mathrm{p}<0.05)$ 가 있었다. Albumin 함량은 무첨가 구는 $4.46 \mathrm{~g} / \mathrm{dl}$ 였으며 $1.0 \%$ 첨가구와 $2.0 \%$ 첨가 구는 각각 $5.25 \mathrm{~g} / \mathrm{dl}$ 와 $5.60 \mathrm{~g} / \mathrm{dl}$ 로서 유의차 $(\mathrm{p}<0.05)$ 가 인정되었다. 그러나 $0.5 \%$ 첨가구는 다른 처 리구와는 차이가 없었다( $\mathrm{p}>0.05)$.

Total cholesterol 함량은 쑥, 두충 및 어성초 의 혼합급여 수준을 증가시킬수록 낮아지는 경 향이지만 무첨가구 $(144.10 \mathrm{mg} / \mathrm{dl})$ 와 $0.5 \%$ 첨가구 $(136.00 \mathrm{mg} / \mathrm{dl})$ 간에는 차이가 없었으며 $(\mathrm{p}>0.05)$, 첨가수준을 $2.0 \%$ 까지 높일 경우에는 $116.23 \mathrm{mg} /$ $\mathrm{dl}$ 로서 유의차 $(\mathrm{p}<0.05)$ 가 있었다. 그러나 $1.0 \%$ 첨가구는 다른 처리구와는 차이가 없었다 $(\mathrm{p}>$ 0.05). LDL 함량은 쑥, 두충 및 어성초의 혼합 급여 수준을 증가시킬수록 감소하는 경향이지 만 무첨가구를 포함한 모든 처리구에서 26.15 $\sim 30.31 \mathrm{mg} / \mathrm{dl}$ 로서 처리구 간에 차이가 없었다 (p>0.05). HDL 함량은 무첨가구는 $69.57 \mathrm{mg} / \mathrm{dl}$ 이 었으며, $1.0 \%$ 첨가구와 $2.0 \%$ 첨가구는 각각 $84.15 \mathrm{mg} / \mathrm{dl}$ 와 $84.25 \mathrm{mg} / \mathrm{dl}$ 로서 유의차 $(\mathrm{p}<0.05)$ 가 있었다. 그러나 $0.5 \%$ 첨가구는 다른 처리구와 는 차이가 없었다 $(\mathrm{p}>0.05)$.

일반적으로 혈중 glucose 함량은 탄수화물의 최종산물로 혈액 내를 순환하며 산화되어 에너 지를 공급하는 역할을 하며, 그 함량은 도살의 방법과 시간에 의하여 크게 좌우되며 도살한 동물의 체조직 함량과 밀접한 관계가 있다(국 등, 2005). 혈청 glucose의 수준은 insulin의 동화 작용과 glucagon, catecholamin과 glucocoricoids의 이화작용에 의하여 변화하는데 insulin과 glucagon 은 서로 길항작용을 하며(Smith, 1989,) 혈중 glucose의 증가는 간에서 당 생산이 증가하고 있음을 의미하며 glucose의 감소는 지방의 분해 로 glucose의 이용이 감소되기 때문인 것으로 알려져 있다(Brockman과 Bergman, 1975). 본 결 과에서 glucose의 함량이 감소하지 않은 것은 지방이 분해되지 않는 것으로 생각되며, 이유 자돈에 있어서 지방의 분해가 일어나지 않는다 는 것은 이유자돈의 생산성의 증가에 좋은 영 향을 줄 것으로 생각된다. Cholesterol은 성호르 몬, 담즙산 및 체내 화합물에 존재하는 생명체 에 필수적인 물질로 보고되고 있으며, 특히 cholesterol 중에서 HDL-cholesterol은 혈관에 침 착되어 있는 cholesterol을 분리시켜 간장에서

Table 6. Effect of dietary bio-active substances on the blood characteristics of weanling pigs

\begin{tabular}{|c|c|c|c|c|}
\hline \multirow{2}{*}{ Blood Characteristics } & \multicolumn{4}{|c|}{ Supplementation levels(\%) of bio-active substances ${ }^{1)}$} \\
\hline & 0.0 & 0.5 & 1.0 & 2.0 \\
\hline Glucose (mg/dl) & $114.04 \pm 10.02^{b}$ & $144.85 \pm 9.78^{\mathrm{a}}$ & $159.07 \pm 8.91^{\mathrm{a}}$ & $138.64 \pm 11.34^{\mathrm{ab}}$ \\
\hline Total protein (g/dl) & $5.70 \pm 0.14^{b}$ & $6.27 \pm 0.19^{\mathrm{a}}$ & $6.45 \pm 0.12^{\mathrm{a}}$ & $6.47 \pm 0.16^{\mathrm{a}}$ \\
\hline Albumin (g/dl) & $4.46 \pm 0.23^{\mathrm{b}}$ & $4.83 \pm 0.31^{\mathrm{ab}}$ & $5.25 \pm 0.15^{\mathrm{a}}$ & $5.60 \pm 0.25^{\mathrm{a}}$ \\
\hline Total cholesterol (mg/dl) & $144.10 \pm 7.45^{\mathrm{a}}$ & $136.00 \pm 10.62^{\mathrm{a}}$ & $129.33 \pm 6.59^{\mathrm{ab}}$ & $116.23 \pm 9.47^{\mathrm{b}}$ \\
\hline $\mathrm{LDL}^{2)}(\mathrm{mg} / \mathrm{dl})$ & $30.31 \pm 1.58$ & $28.94 \pm 1.05$ & $26.15 \pm 1.58$ & $26.60 \pm 1.99$ \\
\hline $\mathrm{HDL}^{3)}$ (mg/dl) & $69.57 \pm 4.04^{\mathrm{b}}$ & $77.26 \pm 3.90^{\mathrm{ab}}$ & $84.15 \pm 4.18^{\mathrm{a}}$ & $84.25 \pm 4.03^{\mathrm{a}}$ \\
\hline
\end{tabular}

1) Mixtures of Artemisia 70\%, Eucommia leaf 15\% and Houttuynia cordata 15\%.

2) LDL: low density lipoprotein.

3) HDL: high density lipoprotein.

${ }^{\mathrm{a}, \mathrm{b}}$ Means \pm SD with different superscripts in the same row differ significantly $(\mathrm{p}<0.05)$. 
Table 7. Effect of dietary bio-active substances on the diarrhea frequency (\%) of nursery pigs

\begin{tabular}{lcccc}
\hline \multirow{2}{*}{ Items } & \multicolumn{4}{c}{ Supplementation levels(\%) of bio-active substances ${ }^{1)}$} \\
\cline { 2 - 5 } & 0.0 & 0.5 & 1.0 & 2.0 \\
\hline \hline Diarrhea & $8.45 \pm 0.43^{\mathrm{a}}$ & $3.85 \pm 0.52^{\mathrm{b}}$ & $0.00 \pm 0.00^{\mathrm{d}}$ & $1.25 \pm 0.48^{\mathrm{c}}$ \\
\hline $\mathrm{n}=3$. & & \\
$1)$ \\
a,b,c,d Mixtures of Artemisia $70 \%$, Eucommia leaf & 15\% and Houttuynia cordata $15 \%$. \\
\end{tabular}

분해시킴으로써 인체에 유익한 cholesterol이고, LDL-cholesterol은 혈관에 침착되어 인체에 해로 운 cholesterol라고 보고하고 있다(박 등, 2003). Baker 등(1984)은 혈중 cholesterol은 동맥경화증, 고혈압 등의 심혈관질환의 요인이 되는 과유지 질혈증을 구성하는 물질인데 과유지질 혈증의 원 인 물질은 LDL cholesterol이라 보고한 바 있다.

따라서 본 연구에서는 생리활성 기능을 가진 쑥, 두충 및 어성초를 $1.0 \%$ 혼합하여 급여할 경 우에는 혈 중 glucose 함량과 HDL-cholesterol 함 량이 증가함으로 이유자돈의 생산성 향상과 복 합적인 면역 증강 작용에 의한 비특이적 면역력 증가(Wagner, 1987)에 효과적일 것으로 생각된다.

\section{5. 설사발생 빈도}

쑥, 두충 및 어성초를 혼합하여 이유자돈 사 료에 첨가수준 $(0.0,0.5,1.0,2.0 \%)$ 별로 급여하 여 이유자돈의 설사발생 빈도를 조사한 결과는 Table 7과 같다.

이유자돈의 설사빈도는 무첨가구가 $8.45 \%$ 였 으며, 쑥, 두충 및 어성초를 혼합 급여함으로서 감소하는 경향이었다. 즉 $0.5 \%, 1.0 \%$ 및 $2.0 \%$ 첨 가구는 각각 $3.85 \%, 0.00 \%$ 및 $1.25 \%$ 로서 모든 처리구에서 유의차 $(\mathrm{p}<0.05)$ 가 인정되었으며, 특 히 $1.0 \%$ 첨가구는 설사가 전혀 발생하지 않았다. 일반적으로 식물 추출물을 가축에게 급여할 경우 사료섭취량 증가, 소화효소의 분비 및 면 역 증강제로서의 역할(Wenk, 2003) 등이 있으 며, 이유 후 식물 추출물인 oreganum essential oil을 첨가할 경우에는 폐사율이 감소한다고 보 고하였다(Maviromaitis와 Kyrikis, 1998). 이는 쏙, 두충 및 어성초의 혼합급여로 복합적인 면 역 증강 작용(Wagner, 1987)과 장내 유익균의 우점을 도와 유해균의 증식을 억제하여 설사가
발생하지 않은 것으로 생각된다. 또한 $0.5 \%$ 첨 가구는 첨가량이 충분치 않아 설사가 $1.0 \%$ 첨 가구보다 많았으며 $2.0 \%$ 첨가구는 그 양이 너 무 많아서 발생빈도가 $1.0 \%$ 첨가구보다 많이 나온 것으로 사료된다.

따라서 이유자돈에 있어서 설사는 폐사로 이 어지는 결과가 많기 때문에 포유자돈에게 생리 활성 물질인 쑥, 두충 및 어성초를 혼합하여 입질사료에 $1.0 \%$ 수준으로 보충. 급여할 경우 이유자돈의 장내 유익균인 Lactobacillius sp.의 증가(Table 5)로 이유 자돈 뿐 만 아니라 포유 중의 설사와 호흡기 질병에 의한 사고를 줄이 는데도 우수한 효과가 있는 것으로 생각된다.

$$
\text { IV. 요 약 }
$$

본 시험은 기능성물질을 함유하고 있는 쑥, 두충 및 어성초를 혼합한 후 배합사료에 0.0 , $0.5,1.0$ 및 $2.0 \%$ 씩 첨가하여 이유자돈에 급여 한 후 증체량, 사료섭취량, 사료효율, 영양소 이용율, 분변의 미생물 총, 가스 발생량, 혈액 성상 및 설사빈도를 조사·분석하여 이유자돈 의 생산성에 미치는 효과를 구명하고자 실시하 였다. 일당 사료섭취량은 $1.0 \%$ 와 $2.0 \%$ 첨가구 가 대조구에 비하여 증가하였다 $(\mathrm{p}<0.05)$. 조단 백질과 조지방 소화율은 $1 \%$ 구가 대조구에 비 하여 증가하였으며 $(\mathrm{p}<0.05), \mathrm{NFE}$ 소화율은 $1.0 \%$ 와 $2.0 \%$ 구가 대조구에 비하여 증가하였다 $(\mathrm{p}<$ 0.05). 분변내 미생물균총 중 Total bacillus는 $1.0 \%$ 와 $2 \%$ 구가 대조구와 $0.5 \%$ 구에 비하여 증 가하였으며, Lactobacillus sp.의 경우에는 $1.0 \%$ 구가 대조구와 $0.5 \%$ 첨가구에 비하여 증가하였 다. 혈 중 glucose 함량은 $0.5 \%$ 와 $1.0 \%$ 구가 대 조구에 비하여 증가하였다 $(\mathrm{p}<0.05)$. Total protein 함량은 모든 첨가구에서 대조구에 비하여 증가 
하였으며 $(\mathrm{p}<0.05)$, Albumin 함량은 $1.0 \%$ 와 $2.0 \%$ 구가 대조구에 비하여 증가하였다 $(\mathrm{p}<0.05)$. Total cholesterol 함량은 $2.0 \%$ 구가 대조구와 $0.5 \%$ 구에 비해 감소하였으며 $(\mathrm{p}<0.05), \mathrm{HDL}$ 함량은 $1 \%$ 와 $2 \%$ 구가 대조구에 비하여 증가하였다 $(\mathrm{p}<0.05)$. 포유자돈의 경우 설사빈도는 크게 감소하였으 며 $(\mathrm{p}<0.05)$, 특히 $1.0 \%$ 구에서는 설사발생이 전 혀 없었다 $(\mathrm{p}<0.05)$.

이상의 시험결과를 종합하면, 쑥, 두충 및 어 성초를 혼합하여 $1.0 \%$ 첨가함으로서 일당증체 량, 사료효율 및 영양소 이용율이 향상되고 설 사 발생빈도가 감소되어 생산성을 증가시킬 수 있을 뿐만 아니라 HDL-cholesterol 함량이 증가 되므로 항생제 대체 물질이 함유된 사료의 개 발이 가능할 것으로 생각된다.

\section{$\mathrm{V}$. 인 용 문 헌}

1. A.O.A.C. 1990. Official Method of Analysis. 16th ed. Association of Official Agricultural Chemist. Washington, D. C. USA.

2. Barker, H. J., Lindsey, J. R. and Weisbroth, S. H. 1984. The laboratory rat. Academic Press Inc., NY. 2:123-131.

3. Barker, J. C. and Zublena, J. P. 1975. Livestock manure nutrient assessment in North Carolina. 7th International Symposium on Agricultural and Food Processing Wastes. p.98-106.

4. Brockman, R. and Berbman, E. N. 1975. Effect of glucagon on plasma alanine and glutamine metabolism and hepatic glucogenesis in sheep. Am. J. Physiol. 228:1327-1331.

5. Deans, S. G. and Ritchie, D. 1987. Antibacterial properties of plant essential oils. International J. Food Microbiol. 5:165-169.

6. Duncan, D. B. 1955. Multiple range and multiple F tests. Biometrics. 11:1.

7. Fox, S. M. 1988. Probiotics/Intestinal Inoculants in Animal Production. Microbial Genetics Division, Pioneer Hi-Bred Intenational, Des Moines, Iowa.

8. Gerbert, S., Messikommer, R. and Wenk, C. 1999. Chinesische kräuter im ferkelfutter. In; Gesunde nutztiere: Umdenken in der Tieremährung? (Sutter,
F., Kreuzer, M. and Wenk, C., ed). p.163-164.

9. Hwang, W. K., Choi, S. B. and Kim, I. H. 1996. Physiological activities of mixed extracts of Acantopancis senticosi radicis cortex and Eucommiae cortex. Kor. J. Pharmacogn. 27:65-72.

10. Kim, J. H., Kim, C. -H. and Ko, Y. D. 2002a. Influence of Dietary Addition of Dried Wormwood (Artemisia sp.) on the Performance and Carcass Characteristics of Hanwoo Steers and the Nutrient Digestibility of Sheep. Asian-Aust. J. Anim. Sci. 15(3):390-395.

11. Kim, Y. M., Kim, J. H., Kim, S. C., Ha, H. M., Ko, Y. D. and Kim, C. -H. 2002b. Influence of Dietary Addition of Dried Wormwood (Artemisia sp.) on the Performance, Carcass Characteristics and Fatty Acid Composition of Muscle Tissues of Hanwoo Heifers. Asian-Aust. J. Anim. Sci. 15(4): 549-554.

12. Ko, Y. D., Kim, J. H., Adesogan, A. T., Ha, H. M. and Kim, S. C. 2006. The effect of replacing rice straw with dry wormwood(Artemisia sp.) on intake, digestibility, nitrogen balance and ruminal fermentation characteristics in sheep. Animal Feed Science and Technology. 125:99-110.

13. Lee, S. H., Woo, S. J., Koo, Y. J. and Shin, H. K. 1995. Effects of mugwort, onion and polygalae radix on the intestinal environment of rats. Korean J. Food Sci. Technol. 27:598-604.

14. Manzanilla, E. G., Perez, J. F., Martin, M., Kamel, C., Baucells, F. and Gasa, J. 2004. Effect of plant extracts and formic acid on the intestinal equilibrium of early-weaned pigs. 82:3210-3216.

15. Mavromatis, J. and Kyriakis, S. C. 1998. Use of origanum essential oils as growth promoter in pigs. Proceedings of the $15^{\text {th }}$ IPVS Congress. Vol. 3. p.221.

16. Metroi, K., Furutsu, M. and Takahashi. S. 1997. The prevention effect of ginseng with Du-Zhung leaf on protein metabolism in pigs. Biol. Pharm. Bull., 20:237-242.

17. Nagy, J. G. and Tengerdy, R. P. 1968. Antibacterial action of essential oils of Artemisia as an ecological factor. I . Antibacterial action of the volatile oils of Artemisia Tridentata(big sagebrush) 
on bacteria from the rumen of muledeer. Appl. Microbiol. 16:441-444.

18. Nakasa, T., Yamaguchi, M., Okinaka, O. and Metori, K. 1995. Effect of Du-chung leaf extract on plasma and hepatic lipids in rats fed on a fat plus high cholesterol diet. Nippon Nogeikagaku Kaihi. 69:1491-1497.

19. SAS. 1999. SAS/STAT Software for PC. Release 6.11, SAS Institute, Cary, NC, U.S.A.

20. Smith, H. W. 1965. The development of the flora of the alimentary trace in young animals. J. Path. Ract. 90:495-513.

21. Smith, R. H. 1989. Nitrogen metabolism in the ruminants stomach. In protein metabolism in farm animals.(Bock, H. D., Eggum, B. O., Low, A. G., Simon, O. and Zebrowska, E. D. S). Oxford University Press. Oxford. p.165.

22. Wagner, H. 1987. In: Hostettmann, K., Lea, P. J.,(Eds.), Biologically Active Natural Products. Clarendon Press, Oxford. p.127.

23. Wenk, C. 2003. Herbs and botanicals as feed additives in monogastric animals. Asian-Aust. J. Anim. Sci. 16:282-289.

24. 국길, 정진형, 김광현. 2005. 죽초액 첨가수준이 비육돈의 육생상성, 혈액성상, 도체성적 및 육질 특성에 미치는 영향. 한국동물자원과학회지. 47 (5):721-730.

25. 권오석, 유종상, 민병준, 손경승, 조진호, 김해진, 진영걸, 김인호. 2005. 사료내 약용식물(인진쑥, 오가피 및 마늘)의 첨가가 포유돈, 포유자돈 및 이유자돈의 성적 및 혈청특성에 미치는 영향. 한 국동물자원과학회지. 47(4):501-512.

26. 김근영, 정동옥, 정희종. 1997. 어성초의 화학성 분 및 항미생물 활성. 한국식품과학회지. 29(3): 400-406.

27. 김옥경. 2002. 어성초 분획물이 사염화탄소로 유 발된 흰쥐의 간손상에 대한 보호효과. 생약학회 지. 33(4):324-331.

28. 김재황, 고영두. 2005a. 쑥(Artemisia sp.)의 가공 방법이 면양의 영양소 소화율과 반추위내 발효 특성에 미치는 영향. 한국동물자원과학회지. 47(3): 409-418.

29. 김재황. 2005. 쑥 Pellet이 면양의 영양소 이용율 과 반추위내 발효특성에 미치는 영향. 한국동물
자원과학회지. 47(3):419-428.

30. 김재황, 고영두. $2005 \mathrm{~b}$. 두충잎의 급여가 면양의 영양소 이용율과 반추위내 발효특성에 미치는 영향. 한국동물자원과학회지. 47(6):955-962.

31. 김재황, 김영민, 이문도, 신재형, 고영두. 2005. 볏짚을 두충잎으로 대체급여 시 거세한우의 생 산성, 도체특성 및 육의 지방산 조성에 미치는 영향. 한국동물자원과학회지. 47(6):983-974.

32. 김지현, 왕수경. 1997. 쑥, 진피, 두충이 고지혈증 흰쥐의 체내 지질대사에 미치는 영향. 한국영양 학회지. 30:895-903.

33. 류익상, 황주광. 1994. 자생식물 쑥, 돌외 및 환 삼덩굴의 지역별, 재배방법별 생육 특성과 주요 약리성분. 약작지. 4(1):27-33.

34. 문관심. 1991. 약초의 성분과 이용. 일월서각. p 127.

35. 박형기, 오홍록, 하정욱, 강종욱, 이근택, 진구복. 2003. 식육과 육제품의 과학과 기술. 선진문화사. 서울. p.34.

36. 백인기. 생균제(Probiotics)의 사용효과. 1989. 한 영사지. 13(3):175-183.

37. 송종호, 김민주, 권혁동, 박인호. 2003. 어성초 뿌 리에서 추출한 순차분획물의 항균활성, 한국식품 영양학회지. 32(7):1053-1058.

38. 이민재. 1965. 약용식물학. 동명사. p 287.

39. 이정호, 정승일, 유일수, 김신기, 이기남, 한두식, 백승화. 2001. 어성초 메탄올 추출물의 카드뮴에 대한 독성억제효과 $(\mathrm{V})$. 생약학회지. 32(1):61-67.

40. 임병용. 1992. 쑥으로부터 추출한 정유의 항균효 과. 한국식품위생안전성학회지. 7:157-163.

41. 전정례, 박정룡. 2002. 두충잎 물 추출물이 사염 화탄소를 투여한 흰쥐의 간 손상에 미치는 영향. 한국식품영양과학회지. 31:124-130.

42. 정보섭, 신민교. 1990. 도해향약(생약) 대사전 식 물편. 영림사. p.551.

43. 허준. 1978. 한방동의보감. 민정사. p.184.

44. 홍종욱, 김인호, 김지훈, 권오석, 이상환, 서완수, 김철, 김을상, 정윤화. 2002. 비육돈에 있어 황기, 인삼, 양파 혼합물의 급여가 성장 및 도체특성에 미치는 영향. 한국식품영양과학회지. 31:149-154.

45. 황윤경, 김동처, 황우익, 항용봉. 1998. 쑥(Artemisia princeps Pampan.) 추출성분의 암세포 증식 억제 효과. 31:799-808.

(접수일자 : 2006. 2. 1. / 채택일자 : 2006. 4. 24.) 